\title{
Analytické teorie metafory: III. Nekognitivní teorie D. Davidsona
}

\section{Analytic Theories of Metaphor: III. Davidson's Noncognitive Theory}

Jakub Mácha

Předložená trojdílná série představuje základní teorie metafory v analytické filosofii: $\mathrm{V}$ první části byly $\mathrm{v}$ předminulém čísle prezentovány počátky interakční teorie u I. A. Richardse, ${ }^{1}$ jak ji podal v knize The Philosophy of Rhetorics (1936). Druhá část osvětlila dnes již klasické podání interakční teorie u M. Blacka (1954-79). ${ }^{2}$ Tato třetí a závěrečná část představuje kritiku interakční teorie od D. Davidsona a jeho nekognitivní teorii (1978).

\section{Nekognitivní teorie D. Davidsona}

V roce 1978 vystoupil Donald Davidson s provokativním článkem What Metaphors Mean, ${ }^{3}$ v jehož úvodu píše, že z větší části nesouhlasí s přístupem Maxe Blacka a mnoha dalších. Hlavní Davidsonova teze neboli výtka Blackovu pojetí je:

1 MÁCHA, J. Analytické teorie metafory: I. Počátky interakční teorie u I. A. Richardse. Studia philosophica. 2020, 67(1), s. 23-29.

2 MÁCHA, J. Analytické teorie metafory: II. Interakční teorie M. Blacka. Studia philosophica. 2020, 67(2), s. 7-19.

3 "The central mistake [...] is the idea that a metaphor has, in addition to its literal sense or meaning, another sense or meaning." DAVIDSON, D. What Metaphors Mean... 
Ústřední chybou [...] je idea, že metafora má kromě svého doslovného smyslu nebo významu další smysl nebo význam. ${ }^{4}$

Pokud toto přijmeme, můžeme většinu výkladu v předchozích dílech této série škrtnout, protože nic jako metaforický význam neexistuje. Na druhou stranu byl tento spor často považován za umělý, protože se týká primárně toho, co je to význam, a ne až toho, jak metafora funguje. ${ }^{5}$ To by ale bylo hrubé zjednodušení. Předešleme, že se Blackovo a Davidsonovo pojetí liší především v tom, kam až lze zajít při explikaci fungování metafory. Davidsonovu práci lze rozdělit na negativní a pozitivní část. V té negativní shrnuje některá pojetí metafory a uvádí argumenty proti nim; pozitivní část pak obsahuje vlastní př́stup. Zde můžeme ještě rozlišovat body, ve kterých je s Blackem zajedno a ve kterých se rozcházejí.

Nejprve uvádí Davidson obecnou tezi, že interpretace metafory závisí na spolupráci tvưrce a čtenáře. Ale již zde si můžeme všimnout, že neř́íká „význam metafory“, nýbrž „interpretace metafory“.

Tedy také pochopení metafory je stejně kreativní úsilí jako produkce metafory a je stejně málo podř́izeno pravidlům. ${ }^{6}$

Tady jako by Davidson vyklízel pole. Jestliže interpretace metafory nepodléhá pravidlům, pak nelze proti žádné z nich, ač třeba absurdní, nic namítat. Ideje metaforického významu nebo metaforické pravdy, tvrdí Davidson, nevysvětlují metaforu, metafora vysvětluje je. To je radikalizováno až do formy (často citovaného) aforismu:

Ale jednoduše vkládat tento význam do metafory je jako vysvětlovat, proč prášek uspává, tím, že má uspávající sílu. ${ }^{7}$

K čemu tedy vůbec potřebujeme teoretické explikace? Stejná námitka by se dala vznést proti explikaci logických zákonů: logické zákony vyplývání (myšlení, chápání...) nevysvětlují, vyplývání vysvětluje je. Davidson trvá na po-

4 Tamtéž, s. 430.

5 Srov. RORTY, R. Unfamiliar noises..., s. 163.

6 "So too understanding a metaphor is as much a creative endeavor as making a metaphor, and as little guided by rules." DAVIDSON, D. What Metaphors Mean..., s. 430.

7 Tamtéž, s. 431: "But simply lodge this meaning in the metaphor is like explaining why a pill puts you to sleep by saying it has a dormative power." 
sloupnosti, že pochopení metafory vede k nějaké metaforické pravdě. Jelikož většina lidí chápe metafory i bez jakéhokoliv pojetí metaforického významu, je konstrukce metaforického významu zbytečná. Pak ale platí stejně: jestliže většina lidí chápe implikaci bez znalosti výrokové logiky, je výroková logika zbytečná. Jako plausibilní se jeví i jiná posloupnost (zmíněná již v poznámce 5 v prvním díle této série): z před-teoretických intuicí budujeme teorii metafory, která nám dále pomáhá ke snadnějšímu pochopení (tř̌eba komplikovanějších) metafor.

Davidson především odmítá ideu, že metafora je forma komunikace. Producent metafory do ní vloží skryté poselství (metaforický význam), které pak příjemce musí dekódovat. Tedy metafora funguje jako šifra, kterou dokáže rozluštit jen náležitě zkušený čtenář. Nazvěme tento pohled na metaforu kryptografický. I když je jeho formulace zcela obecná, je patrně zřejmé, že zahrnuje substituční pohled, který diskutoval Max Black. Otázka ale zní, zda lze pod kryptografický pohled zahrnout i Blackovu interakční teorii. ${ }^{8}$

Davidson něco jako metaforickou interpretaci připouští:

At již metafora závisí nebo nezávisí na nových nebo rozšířených významech [slov], určitě závisí nějakým způsobem na původních významech [slov]. ${ }^{9}$

Není přesně jasné, čeho se toto tvrzení týká. Předpokládejme, že se jedná o interpretaci metafory (když už nechce Davidson připustit význam metafory). Pak je tato věta zcela triviální (ostatně platí pro všechny tropy), protože její opak je málo pochopitelný.

V dalším kroku je metafora diskutována jako jistý druh víceznačnosti (ambiguity). Davidson nabízí tři schémata (schéma 1-3 na obr. 1), jak je možné chápat metaforu jako víceznačnost. Při posuzování té či oné metafory je možné nalézt všechny tři typy víceznačnosti.

Všimněme si prvního a třetího schématu. Víceznačnost spočívá ve volbě mezi doslovným a metaforickým (obrazným) významem. Schéma tři je sofistikovanější v naznačené závislosti obrazného významu na původním významu. Druhé schéma vidí víceznačnost metafory v množství interpretací, ale

8 Ačkoliv to Black popírá, je třeba důkladnější analýzy. Srov. BLACK, M. How Metaphors Work..., pozn. 24: “[B]ut no moderately attentive reader of my own writings on metaphor could suppose that I ever maintained that metaphorical statements are primarily used 'for conveying ideas'."

9 "Whether or not metaphor depends on new or extended meanings, it certainly depends in some way on the original meanings." DAVIDSON, D. What Metaphors Mean..., s. 432. 

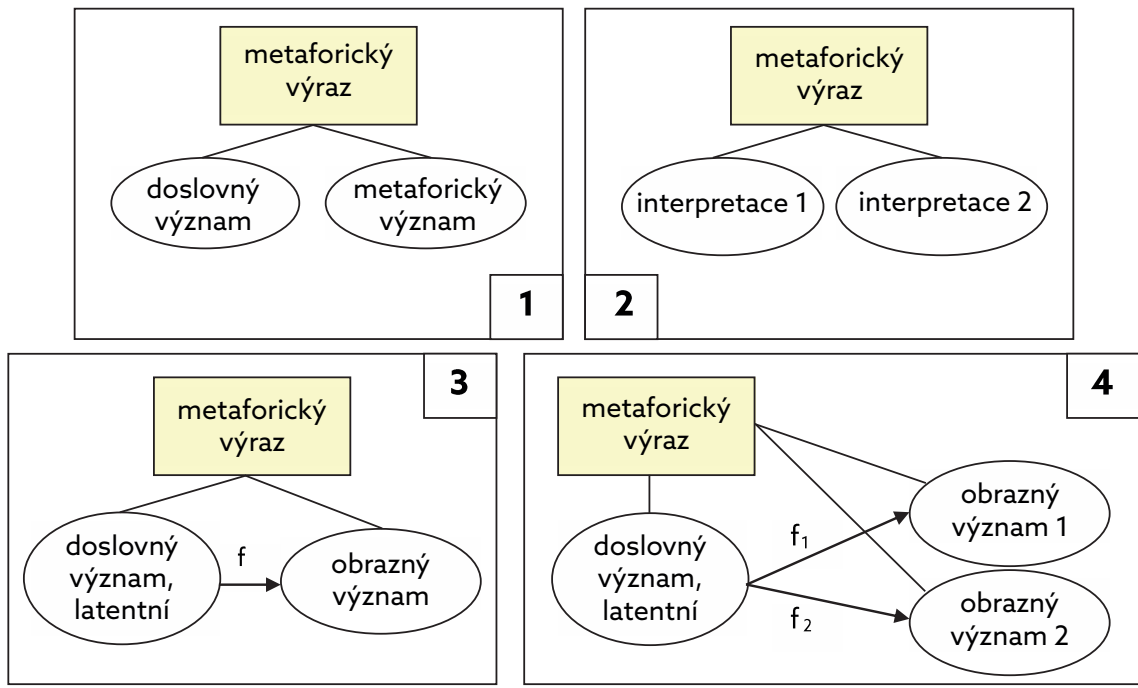

Obr. 1. Typy víceznačností

postrádá vazbu na původní význam. Davidson tato tři schémata diskutuje a pracovně se přiklání k druhému i třetímu. Všechna tři schémata odpovídají kryptografickému pohledu. Bohužel ale nediskutuje čtvrté schéma, které je nejbližší teorii Maxe Blacka. V tomto schématu jsou podstatou víceznačnosti metafory různé možnosti transformace původních významů slov. Davidson tato pojetí odmítá typickým argumentem postanalytické filozofie, k níž se sám hlásí: v praxi často nelze rozhodnout, kdy je výraz použit metaforicky a kdy se jedná o jeho doslovné, leč dřive neznámé použití. Nebo jinými slovy:

Událost metafory by tak byla př́ležitostí k naučení nového významu. ${ }^{10}$

Tato myšlenka není nezajímavá, protože letmým pohledem do etymologického slovníku lze zjistit, že vývoj mnoha slov probíhal na základě metaforického přenosu. Existují teorie, které př́imo fungování metafory a učení se jazyka převádějí na společný princip. ${ }^{11}$ Davidson ve svém př́istupu rozlišuje mezi učením a použitím jazyka a říká:

10 "[T]he occasion of the metaphor would, therefore, be the occasion for learning the new meaning." DAVIDSON, D. What Metaphors Mean..., s. 434.

11 Např́íklad práce BARTSCH, R. Dynamic Conceptual Semantiscs... 
V prvním případě [...] je naše pozornost směřována $\mathrm{k}$ jazyku, $\mathrm{v}$ druhém $\mathrm{k}$ tomu, o čem jazyk je. Metafora [...] náleží do té druhé kategorie. ${ }^{12}$

To si žádá několik poznámek: Davidson zde využívá diferenci pozdního Wittgensteina mezi významem slov a jejich použitím. ${ }^{13} \mathrm{Na}$ jednu stranu se jedná o nutnou konsekvenci Davidsonova pojetí významu, k jehož rozboru se dostaneme dále. ${ }^{14} \mathrm{Na}$ druhou stranu, pokud se metafora týká toho, o čem je jazyk, týká se referentů. Davidson tak vyklízí doménu významu a vrací se ke starší srovnávací teorii, jak poznamenal Max Black. ${ }^{15} \mathrm{~K}$ Davidsonovu pozitivnímu návrhu se ještě dostaneme. Pokud ale připustíme, že př́ijemce metaforického výrazu si není jistý, zda jej má brát jako metaforu nebo výuku významu slov, zhroutí se všechna čtyři výše uvedená schémata a stejně tak i Davidsonova teze, že metafora závisí na původních významech slov. V tomto př́ípadě není žádný „původní význam“ a interpretace metafory nemůže vůbec začít. Je zřejmě pochopitelné, že metafory mohou interpretovat pouze do jisté míry zkušení uživatelé jazyka.

Podle kryptografického pohledu je možné ztotožnit metaforický význam živé metafory s doslovným významem mrtvé metafory. Ale pravé metafory, dodává Davidson, zůstávají metaforami i na stý poslech. Metafory fungují znova a znova, proto nemůže jejich princip záviset na překvapení, ohromení nebo údivu (na rozdíl od vtipu). Spíše se musí jednat o „vestavěný estetický prvek“ (built-in estetic feature). To ale nemůže být závěr úvah, nýbrž jejich východisko. Opakovatelnost metafory je nutné zabudovat do teoretického modelu. Obecně podle kryptografického modelu totiž zpráva přestává být šifrou, jakmile je jednou dešifrována. To je také jeden z hlavních argumentů proti tomuto modelu.

V tomto ohledu posunul Davidsonův přístup Richard Rorty, ${ }^{16}$ který postavil do popředí právě moment překvapení. Pro něj je metafora neobvyklý a nepredikovatelný způsob použití jazyka, a proto ji také nelze vysvětlit žádným schématem:

12 "[I]n one case [...] our attention is directed to language, in the other to what language is about. Metaphor [...] belongs to the second category." DAVIDSON, D. What Metaphors Mean..., s. 434.

13 Wittgenstein ale na rozdíl od Davidsona diferenci mezi oběma smazává tím, že význam převádí na použití.

14 Souvislost je analyzována v RORTY, R. Unfamiliar noises...

15 BLACK, M. How Metaphors Work..., s. 189.

16 RORTY, R. Unfamiliar noises... 
Jestliže „pochopení“ nebo „interpretováni“ znamená „podřízení pod stávající schéma“, pak metafory nemohou být pochopeny nebo interpretovány. ${ }^{17}$

Otázka „Jak funguje metafora?" je stejně nezodpověditelná jako otázky „Co je podstatou neočekávaného?“ nebo „Jak fungují překvapení?“.

\section{Přirovnání a metafora}

Davidson srovnání metafory a přirovnání věnuje poměrně mnoho místa a podrobnější analýza ukáže, že se ve svých závěrech přiliš nevzdaluje od Blacka. Diskutovány a odmítnuty jsou dvě teorie, které vysvětlují metaforu na základě přirovnání: (1) metafora je eliptické přirovnání (tzn. metafora je zkratkou pro přirovnání) a (2) speciální význam metafory je identický s doslovným významem odpovídajícího přirovnání. První teorie stírá jakýkoliv významový rozdíl mezi metaforou a přirovnáním. Davidson tyto dvě teorie odmítá s tím, že př́liš zviditelňují skrytý význam metafory; analýza metafory by pak byla velmi snadná. Ale před uznáním těchto výtek je třeba si vyjasnit pojetí doslovného a obrazného významu přirovnání. Přrirovnání ve svém doslovném významu vyjadřuje podobnost dvou věcí. Napřríklad přirovnání „geometrický důkaz je jako past na myši“ vyjadřuje nějakou podobnost mezi referenty, tj. mezi geometrickými důkazy a pastmi na myši. Vysvětlení toho, v čem tato podobnost spočívá, ale není podle Davidsona doslovným významem přirovnání, "protože přirovnání netvrdí nic více než tuto podobnost“. ${ }^{18} \mathrm{~V}$ tom případě převedení metafory na přirovnání nic neřeší, protože to neříká o mnoho více. Metafory a přirovnání mají jistý společný mód fungování, to také připouští Davidson formulací:

Přirovnání tvrdí, že existuje podobnost, a nechávají na nás, abychom si zvolili nějakou běžnou vlastnost nebo vlastnosti; metafora netvrdí explicitně podobnost, ale když ji akceptujeme jako metaforu, opět jsme navedeni k hledání běžných vlastností (ne nutně těch samých jako u odpovídajícího přirovnání; ale to je jiná věc). ${ }^{19}$

17 "If 'understanding' or 'interpreting' means 'bringing under an antecedent scheme', then metaphors cannot be understood or interpreted.” Tamtéž, s. 167.

18 "...since the simile declares no more than the similarity". DAVIDSON, D. What Metaphors Mean..., s. 435.

19 "The simile says there is a likeness and leaves it to us to pick out some common feature or features; the metaphor does not explicitly assert a likeness, but if we accept it as a meta- 
Rozdíl mezi metaforou a přirovnáním se tak přesouvá do úrovně detekce metafory. Jakmile je metafora detekována, funguje stejně jako přirovnání. Tomuto vysvětlení nasvědčuje i další Davidsonova formulace:

Nejzjevnější sémantický rozdíl mezi přirovnáním a metaforou je v tom, že všechna přirovnání jsou pravdivá a většina metafor je nepravdivá. ${ }^{20}$

Odmítnutí obrazného významu metafory vede Davidsona $\mathrm{k}$ jeho upření i u přirovnání a pak jediný (sémantický) rozdíl spočívá v (doslovné) pravdivosti. ${ }^{21}$ Tento směr uvažování mu také vytýká Black:

Davidson zde, a po celou dobu, zjevně přehlí̌zí fakt, že přirovnání může být obrazné. ${ }^{22}$

Následující Davidsonova pasáž chápe dokonce přirovnání jako speciální případ metafory a v podstatě říká totéž, co stojí v předposledním odstavci kapitoly o přirovnání u Maxe Blacka:

Čeho je možné dosáhnout doslovným významem slov v přirovnání, toho musí být možné jím dosáhnout v metafoře. Metafora směřuje pozornost ke stejným typům podobnosti, když ne ke stejným podobnostem jako odpovídající přirovnání. Pak ale neočekávané nebo subtilní paralely a analogie, jejichž prosazování je záležitostí metafory, nezávisí, při jejich prosazování, na ničem jiném než doslovném významu slov. ${ }^{23}$

phor, we are again led to seek common features (not necessarily the same features the associated simile suggests; but that is another matter).” Tamtéž, s. 436.

20 "The most obvious semantic difference between simile and metaphor is that all similes are true and most metaphors are false." Tamtéž, s. 437.

21 Připomeňme, že stále existuje syntaktický rozdíl (přirovnání mají typicky frázi ,jako“).

22 "Davidson here, and throughout, apparently overlooks the fact that a simile can be figurative." BLACK, M. How Metaphors Work..., s. 186, pozn. 23.

23 "What words do do with their literal meaning in simile must be possible for them to do in metaphor. A metaphor directs attention to [...] the same similarities, as the corresponding simile. But the unexpected or subtle parallels and analogies it is the business of metaphor to promote need not depend, for their promotion, on more than the literal meanings of words." DAVIDSON, D. What Metaphors Mean..., s. 436. 
Na jiném místě používá Davidson formulaci „začneme hledat skrytou implikaci“. ${ }^{24}$

\section{Význam}

Davidson tvrdí, že metafora nemá kromě svého doslovného významu žádný jiný význam. Klíčem k pochopení tohoto překvapujícího tvrzení je Davidsonovo pojetí významu. Hlavní již zmíněnou myšlenkou, na které stojí Davidsonův článek, je diference mezi tím, co slova znamenají (významem), a tím, k čemu jsou použita (užitím). Metafora pak náleží do kategorie užití, ergo metafora nemá žádný význam. Zjednodušeně lze říct, že Davidsonův článek je jen rozvinutím této myšlenkové figury. V článku o metafoře říká o významu:

Smyslem konceptu lingvistického významu je vysvětlit, co lze učinit se slovy. ${ }^{25}$

Metaforický význam ale nemůže být vlastností jednotlivých slov, nýbrž musí funkčně záviset na jejich kombinaci. Jelikož kombinace slov jsou neomezené, nemůže existovat něco jako slovník metafor. ${ }^{26}$ Jestliže mluví Davidson o metaforickém významu, osciluje tak mezi dvěma pojetími: (1) význam vybraných slov v metafoře a (2) význam metafory jako celku. Primární, zdá se, je pro něj první pojetí. Odmítnutí metaforického významu jednotlivých slov pak implikuje odmítnutí metaforického významu celé metafory. Zkusme to doložit citáty. Druhé pojetí metaforického významu naznačuje citát uvedený výše: „metafora má kromě svého doslovného [...] významu další [...] význam“. První pojetí je možné ilustrovat citátem:

[V]ěty, v nichž se vyskytuje metafora, jsou pravdivé nebo nepravdivé normálním, doslovným způsobem, protože jestliže slova v nich nemají speciální významy, věty nemají speciální pravdivost. ${ }^{27}$

24 “...start to hunt out the hidden implication.” Tamtéž, s. 437.

25 "The point of the concept of linguistic meaning is to explain what can be done with words." Tamtéž, s. 436.

26 Slovník metafor nemůže existovat ještě z jiného důvodu: metaforický význam či interpretace závisí na producentovi i př́ijemci.

27 "[T]he sentences in which metaphor occur are true or false in a normal, literal way, for if the words in them don't have special meanings, sentences don't have special truth." Tamtéž. 
Podstatou Blackovy interakční teorie je jiný způsob kombinace významů slov v metaforické větě. Tento způsob spojení částí v celek můžeme nazvat „speciální“, protože „normální“ spojení významů slov většinou vede k nepravdě. Musíme si ale uvědomit, že způsob kombinace slov a případně jiných lingvistických jednotek do vět a vyšších celků je možné nazvat jejich užitím. Tato úvaha tak vede $\mathrm{k}$ sblížení obou teorií. ${ }^{28}$

Na jiném místě uvádí Davidson psychologický pohled na věc: hranice mezi doslovným a metaforickým užitím slov je neurčitá (fuzzy) a ustanovuje se až použitím v jistém kontextu. Tato neurčitost je jistě pochopitelná a lze ji ilustrovat na příkladech, nicméně distinkci mezi oběma použitími Davidson navrhuje zachovat:

Ale přece tato neurčitost nemůže vymazat linii mezi tím, co věta doslova znamená (v daném kontextu), a tím, k čemu „poutá naši pozornost“ (daným v kontextu fixovaným významem). ${ }^{29}$

V tomto popisu lze význam interpretovat fregovsky jako spojení mezi slovem a tím, k čemu odkazuje, jako „způsob udání“ ${ }^{30}$. Frázi „k čemu poutá naši pozornost“ je možné považovat za Fregův význam (Bedeutung), dnes bychom řekli referent. Ten ale Davidson chápe psychologicky a směšuje jej s představou o něm, zcela proti dikci Fregova textu:

Je třeba odlišovat význam a smysl nějakého znaku od představy, která je s ním spojena. ${ }^{31}$

Tato skutečnost bude hrát roli dále při Blackově kritice Davidsonova pojetí metafory.

28 Fregův princip kompozicionality lze vyjádřit slovy Františka Gahéra: „Význam zloženého výrazu je určený významami jeho podvýrazov a spôsobom zreţazenia týchto podvýrazov, ktorý zachytáva spôsob spojenia jednotlivých významov." (GAHÉR, F. Fregeho filozofia matematiky a program logicizmu..., s. XXII). Metaforický význam se liší od doslovného ve způsobu spojení významů svých částí a ne (nebo jen nepodstatně) změnou jejich významu. Metafora tak nemusí být nutně chápána jako porušení tohoto principu.

29 "But surely this fuzziness [...] cannot erase the line between what a sentence literally means (given its context) and what it 'draws attention to' (given its literal meaning as fixed by the context).” DAVIDSON, D. What Metaphors Mean..., s. 438.

30 Srov. FREGE, G. Über Sinn und Bedeutung..., s. 37.

31 Tamtéž, s. 40. 
Richard Rorty ${ }^{32}$ se snaží o mírně jiné objasnění Davidsonova pojetí významu. Význam má roli jen v úzce vymezené oblasti regulárního, predikovatelného lingvistického chování. To pak osvětluje citátem Akeela Bilgramiho:

Lingvistický význam je teoretické jádro, které je nezbytné ve vysvětlení našeho používání jazyka - a tak je v něm, nepřekvapivě, manifestováno [...]. Smyslem metody radikální interpretace je destilování nebo abstrahování tohoto teoretického jádra ze schváleného schování agenta (kombinací pozorování světa okolo agenta a aplikace principu vstřícnosti). ${ }^{33}$

Toto ale Davidson omezuje jen na význam jednotlivých slov. Principiálně nám nic (kromě větší složitosti a zřejmé časové náročnosti) nebrání odvodit teoretické jádro fungování metafor jako druhý krok po určení významů slov.

\section{Pozitivní pojetí metafory u Davidsona}

Negativní část Davidsonova článku je zaměřena proti pojetí, které jsme nazvali kryptogragické. Teorie metafory by tak podle něj neměla poskytovat metodu, jak dešifrovat skrytý obsah, nýbrž objasnit něco z efektu metafor na nás. Rorty to komentuje slovy:

Davidson může spokojeně souhlasit s pozitivisty, že tyto efekty jsou spíše "psychologické“ než „logické“. ${ }^{34}$

To budiž shrnutí Davidsonova př́ístupu. Fungování metafory, tento efekt na nás, nemůže být vysvětlen jako jazykový význam. Nicméně je ale zřejmé, že v metafoře tušíme něco více, než je pouhý význam slov, ze kterých se skládá. Davidson se zdráhá to „něco více“ nazvat kognitiuním obsahem, který je přisu-

32 Srov. RORTY, R. Unfamiliar noises..., s. 163n.

33 RORTY, R. Unfamiliar noises..., s. 164, pozn. 9, citace z BILGRAMI, A. Meaning, Holism and Use..., s. 120-121: "[L]inguistic meaning is a theoretical core that is indispensable in the explanation of our use of language - and so, unsurprisingly, manifest in it. [...] The point of the method radical interpretation is to distill or abstract out of the assent behaviour of an agent (via a combination of observation of the world around the agent and an application of the constraint of charity) this theoretical core."

34 "Davidson can cheerfully agree with the positivists that these effects are 'psychological' rather than 'logical'." RORTY, R. Unfamiliar noises..., s. 168. 
zován kryptografickému pojetí. Na tomto místě je třeba objasnit status toho „něco více“ a pak přijatelně explikovat pojem kognitivního obsahu.

V našem hypotetickém kryptografickém pojetí metafora skrývá další, metaforický význam, tudíž jako „něco více“ tvrdí tento význam. Davidson zpochybňuje, že se jedná o tvrzení (assertion) nějakého propozičního obsahu, a navrhuje používat termín „naznačuje“ (intimate). Své pojetí přirovnává v tomto bodě k Hérakleitovu výroku o delfské věštírně: „Netvrdí ani neskrývá, naznačuje. " ${ }^{35}$ Jde o to, že podle Davidsona a také Blacka ${ }^{36}$ zde nelze použít slovesa „tvrdit“ (say) nebo „znamenat“ (mean). Black v reakci na Davidsona používá termínu „allude“ neboli „dělat narážky“, což se od slova „intimate“ čili „naznačovat“ př́liš neliší.

To, co metafora naznačuje, nemá obecně propoziční charakter, tedy nejedná se o tvrzení, které může být pravdivé či nepravdivé. Davidson se úplně nezříká metaforické pravdivosti, ale nepřisuzuje ji větám, nýbrž vizím, emocím a pocitům:

Metafora nás vede k povšimnutí si toho, co by nemuselo být jinak povšimnuto, a není důvodu [...] neříci, že tyto vize, myšlenky a pocity inspirované metaforou jsou pravdivé nebo nepravdivé. ${ }^{37}$

Přisuzování pravdivosti psychologickým fenoménům je velmi nezvyklé, ale pokusme se přesto sledovat Davidsona dále. Zcela v Blackově duchu mohou k těmto vizím a pocitům patřit „překvapující analogie a podobnosti“, které vytváří jistý druh „čoček nebo mřížku“, skrze níž vidíme relevantní fenomén. ${ }^{38}$ Tento v psychologickém významu míněný obsah přirovnává Davidson k fotografii, k něčemu obrazovému:

35 "It does not say and it does not hide, it intimates." DAVIDSON, D. What Metaphors Mean..., s. 439.

36 Srov. BLACK, M. How Metaphors Work..., s. 184, pozn. 17: "I am trying to acknowledge, however inadequately, the aspects of a metaphor's working that cannot plausibly be subsumed under implicit "saying."”

37 DAVIDSON, D. What Metaphors Mean..., s. 438: "Metaphor does lead us to notice what might not otherwise be noticed, and there is no reason [...] not to say these visions, thoughts, and feelings inspired by the metaphor, are true or false."

38 Srov. tamtéž, s. 439. 
Kolik faktů nebo propozic může být vyjádřeno fotografií? [...] Slova nelze směnit za obraz. ${ }^{39}$

Fotografie je slovy do jisté míry popsatelná a záleží na našem pojmovém aparátu, zda je popsatelná konečným nebo nekonečným počtem vět. Tento směr ale Davidson rovněž nepřijímá s poukazem na Wittgensteinův př́klad s kačeno-králíkem (duck-rabbit). Davidsonova úvaha by se patrně dala zrekonstruovat následovně: emotivnímu obsahu metafory zde odpovídá vyobrazení kačeno-králíka. Jelikož existuje více stejně hodnotných, avšak odporujících si popisů tohoto vyobrazení, nemůžeme se uchýlit k žádnému z nich a musíme považovat vyobrazení kačeno-králíka za nepopsatelné; tudíž emotivní obsah metafory by byl taktéž nepopsatelný a neparafrázovatelný. Myslím, že smysl tohoto př́kladu je mírně odlišný. Wittgenstein poukazuje na to, že „sdělením vnímáni““40 (Mitteilung der Wahrnehmung) není prosté „vidění“ (Sehen). Věta „Je to králík.“ je sdělením vnímání, věta „Ted’ je to králík.“ ne, protože zahrnuje implicitní předpoklad, že tento popis se může změnit, aniž by se změnil popisovaný předmět. To Wittgenstein nazývá výrazem „změna aspektu“ (Aspektwechsel). „,Vidění jako“ nenáleží ke vnímání,“ a tudíž je zde něco, co náleží vnímajícímu. Wittgenstein tak buduje diferenci mezi „stálým viděním aspektu“ (stetigen Sehen eines Aspekts) a „napadnutím aspektu“ (Aufleuchten des Aspekts - doslova „zazáření aspektu“). Prvnímu odpovídá sdělení vnímání jako myšlenkový výraz (Gedankenausdruck), který není nutně spjat s prožitkem vidění (Sehererlebnis); napadnutí aspektu odpovídá zvolání jako bezprostřední myšlenkový výraz prožitku vidění. Pouze druhý případ představuje jednotu myšlení a prožívání, je to „napůl prožitek vidění, napůl myšlení“. Davidsona na tomto příkladu zajímá právě tato nerozlučnost myšlení a prožívání. Tu ale Wittgenstein spojuje s náhlým uviděním jistého aspektu nazíraného předmětu, a tudíž s překvapením. Lze tak konstatovat, že poukazem na příklad s kačeno-králíkem, resp. jeho zapojením do vlastních úvah o fungování metafory se Davidson dostává do rozporu se svým předchozím tvrzením, že princip metafory závisí spíše na „vestavěném estetickém prvku“ než na překvapení a ochromení.

Sblížením momentu myšlení a psychologického účinku se Davidson blíží pojetí Paula Ricoeura, který připisuje sémantickou funkci psychologickým

39 "How many facts or propositions are conveyed by a photograph? [...] Words are the wrong currency to exchange for a picture." Tamtéž, s. 440.

Srov. WITTGENSTEIN's Nachlass, položka 144, s. 39nn. 
prvkům metafory, a tak se explicitně vymezuje proti Fregově a Husserlově dichotomii mezi smyslem jako objektivním obsahem a představou (Vorstellung) jako mentální aktualizací či reprezentací. ${ }^{41}$ Pokud je referentem metaforického výrazu slovy nepopsatelná psychologická entita, nelze fungování metafory dále vysvětlit. To je také důsledek nerozlišení mezi referentem a jeho psychologickou realizací, tj. konkrétní představou. V tomto smyslu může Black říct:

Davidsonova pozice se redukuje na reformulaci staré, a mohli bychom doufat, zdiskreditované teorie, kterou jsem dříve nazval „srovnávací pohled“. ${ }^{4}$

Na tomto místě se Davidson nejvýrazněji vzdaluje od interakční teorie Maxe Blacka. Uznejme naopak spolu s Blackem za možné, že tyto psychologické obsahy připouštějí slovní vyjádření. Interakční teorie, které jsme se věnovali v předchozích článcích, v podstatě tvrdí, že právě libovolné slovní vyjádření psychologického obsahu je metaforickým významem. Tato vyjádření něco vyjadřují a tento obsah by byl tím skrytým poselstvím v našem kryptografickém pohledu. Proto ani Davidson ani Black pro ně nepoužívají sloveso „tvrdit“ (say), nýbrž „naznačovat“ (intimate) nebo „dělat narážky“ (allude). Jedná se o různé jazykové akty, jak poznamenává Black:

[Davidson] se zajímá více o to, co by Austin nazval perlokučním efektem metaforického diskurzu, než o jakoukoliv postulovanou ilokuční sílu metaforické promluvy. ${ }^{43}$

Producent metafory sice dělá pouze narážky, které však podle Blacka mohou implikovat pravdivostní tvrzení (propozice). Z této potíže se pak dostává poukazem na své dřívější tvrzení, že „množina takto získaných doslovných

41 Srov. RICOEUR, P. The Metaphorical Process as Cognition, Imagination, and Feeling..., s. 142.

42 "Davidson's position reduces to a reformulation of the ancient and, as one might have hoped, discredited theory that I have in the past called a 'comparison view'." BLACK, M. How Metaphors Work..., s. 189.

43 "[Davidson] is more interested in what Austin would have called the perlocutionary effects of metaphorical discourse than in any postulated illocutionary force of metaphorical utterance.” Tamtéž, s. 188. 
výpovědí nebude mít stejnou sílu informovat a poučit jako originál“. ${ }^{44}$ Dostáváme se tak opět k nutnosti vymezení pojmu kognitivní obsah, což neučinil ani Black ani Davidson.

Rorty interpretuje diferenci mezi tvrzením a naznačováním několika slovními páry. Metafora sice nevyjadřuje vědění (express knowledge), ale zajištuje jej (gain knowledge). ${ }^{45} \mathrm{Na}$ jiném místě pak dodává, že metafora je stimulem k vědění (stimulus to knowledge), ale nepřenáší jej (convey knowledge). ${ }^{46}$ Ve stejném odstavci se pak můžeme dočíst, že metafora může být prŕíčinou přesvědčení (cause of belief), ale ne jeho ospravedlněním (justification of belief) nebo opodstatněním (reason of belief). ${ }^{47}$ Všechny tyto formulace se snaží o lavírování mezi dvěma póly, které jsou oba nepřijatelné: (1) kryptografickým pohledem, že metafora obsahuje skryté sdělení, a (2) upřením jakékoliv souvislosti mezi metaforou a poznáním.

\section{Kognitivní obsah metafory}

Kognitiuni obsah má poznávací hodnotu. Nám ted’ jde o to, jak tuto hodnotu postihnout. Dalo by se sáhnout k některému z vymezení konceptu informace či informační hodnoty. Black i Davidson používají informační hodnotu doslovného významu k detekci metafory. Zjevně nepravdivé či absurdní tvrzení má nízkou informační hodnotu (tj. míru informace), a tak se je příjemce snaží pokládat za metaforu a také tak interpretovat. To ale činí za účelem zvýšení informační hodnoty, protože jinak by toto kritérium detekce nemělo smysl. Jinak řečeno: abychom mohli považovat nízkou informační hodnotu za kritérium detekce metafory, musíme vypracovat koncept informačního (kognitivního) obsahu metaforického výrazu a tento obsah musí obecně poskytovat více informace než doslovný význam téhož výrazu.

Implikace, které př́ijemce může z metafory odvodit, mohou být vysoce informativními tvrzeními. Ale pokud tyto implikace bez dalšího prohlásíme za metaforický význam metafory, stane se jejich kognitivní obsah kognitivním obsahem metafory. To ale vede přímo ke kryptografickému pojetí. Infor-

44 Tamtéž, s. 191 nebo též BLACK, M. Metaphor..., s. 46: "[T]he set of literal statements so obtained will not have the same power to inform and enlighten as the original."

45 RORTY, R. Unfamiliar noises..., s. 168.

46 Tamtéž, s. 169.

47 Tamtéž, s. 169 a 171. 
mační hodnotu implikací můžeme zmírnit relativizováním podle konkrétních preferencí.

Pokusme se navrhnout jedno z takových řešení. Vyjděme $\mathrm{z}$ jednoduché myšlenky, že informační hodnota zdroje zpráv je váženým průměrem informační hodnoty jednotlivých zpráv. Přesněji: jestliže zdroj $Z$ emituje zprávy $Z_{1}$ a $Z_{2}$ s pravděpodobnostmi $p$ a $1-p($ kde $0 \leq p \leq 1)$ a necht' In je informační funkce přiřazující jednotlivým zprávám míru informace, kterou poskytují. Pak lze funkci In přirozeně rozšíritit i na zdroj $Z$ podle předpisu

$\operatorname{In}(\mathrm{Z})=p \cdot \operatorname{In}\left(\mathrm{Z}_{1}\right)+(1-p) \cdot \operatorname{In}\left(\mathrm{Z}_{2}\right)$.

Úvahu je pak možné jednoduše rozšíríit na libovolný konečný počet zpráv. Aplikováno na jazykové výrazy: necht’ výraz $V$ je dvojznačný, tj. mající významy $V_{1}$ a $V_{2}$, pak jeho informační hodnota

$\operatorname{In}(\mathrm{V})=p_{1} \cdot \operatorname{In}\left(\mathrm{V}_{1}\right)+p_{2} \cdot \operatorname{In}\left(\mathrm{V}_{2}\right)$,

kde $p_{1}$ a $p_{2}$ jsou relativní pravděpodobnosti jednotlivých významů a $p_{1}+p_{2}=1$.

Víceznačnost je v Blackově interakčním modelu bytostně na dvou místech: jednak se jedná o volbu implikačního komplexu a pak o relativní váhy jeho jednotlivých složek. Ponechme ponejprv implikační komplex pevný (protože je více závislý na kontextu promluvy) a konstruujme informační hodnotu na základě relativních vah jednotlivých implikací. Pak informační hodnota metaforického tvrzení „P je S“ je dána vzorcem:

$\operatorname{In}_{\text {MET }}\left(, P\right.$ je $\left.S^{\prime}\right)=\sum p_{i} \cdot \operatorname{In}\left(, P\right.$ je $\left.I\left(t_{i}\right) . “\right)$,

kde suma je indexována koeficientem $i, p_{i}$ jsou relativní váhy jednotlivých položek implikačního komplexu, který je konstruován ve schématu interakce, které je popsáno v předešlém díle. ${ }^{48}$ Vzorec by šlo zobecnit i na různé (potenciálně nekonečné) implikační komplexy, což by ale vyžadovalo přesnější explikaci celé struktury. Ponechme tak nastíněné vypracování kognitivního obsahu jen v rovině návrhu.

Tvůrce metafory ale nemusí tvrdit žádné z těchto tvrzení. Pokud by je tvrdil, pak by byla metafora prostředkem k jejich transportu k př́jemci, což je zavrhované kryptografické pojetí. Kognitivní obsah implikací metafory

48 MÁCHA, J. Analytické teorie metafory: II..., s. 11. 
nemůže být směšován s kognitivním obsahem metafory samotné. Ten pak musí ležet v samotné interakci, která je u Maxe Blacka zachycena izomorfizmem I. Fakt strukturního izomorfizmu mezi primárním a sekundárním subjektem je podstatou implikačního komplexu a logicky předchází jednotlivé implikace. Informační hodnota by mohla být vyjádřena mohutností domény tohoto izomorfizmu. Ta nemusí být na straně producenta a na straně příjemce stejná, ale právě to vystihuje podstatu metafory. Informační hodnota jako míra kognitivního obsahu závisí na kreativním úsilí (Davidsonovo creative endeavour) př́ijemce. Analýza kognitivního obsahu metafory pomocí pojmu informační hodnoty tedy odhaluje jistou asymetrii mezi producentem a příjemcem. Nejedná se o hru s nulovým součtem. Př́ijemce může získat více kognitivní hodnoty, než producent zamýšlel do metafory vložit.

Tímto končí trojdílná série textů o analytických teoriích metafory. V původním rukopisu z roku 2006 byla bodově naznačena pragmatická teorie J. Searla, kterou ale nebylo možné zařadit do této série. Na přehledové zpracování této teorie a mnohých dalších, včetně argumentů pro a proti, odkazuji na můj anglický článek „Metaphor in Analytic Philosophy and Cognitive Science“ (2019). ${ }^{49}$

\section{Seznam použitých zdrojů}

BARTSCH, Renate. Dynamic Conceptual Semantiscs. Cambridge: Cambridge University Press 1998.

BILGRAMI, Akeel. Meaning, Holism and Use. In LEPORE, E. (ed.). Truth and Interpretation: Perspectives on the Philosophy of Donald Davidson, Oxford: Basil Blackwell 1986.

BLACK, Max. How Metaphors Work: A Reply to Donald Davidson. In SACKS, S. (ed.). On Metaphor. Chicago: University of Chicago Press 1978, s. 181-92.

BLACK, Max. Metaphor. In Models and Metaphors. Ithaca: Cornell University Press 1962, s. 25-47.

DAVIDSON, Donald. What Metaphors Mean. In SACKS, S. (ed.), On Metaphor. Chicago: University of Chicago Press 1978, s. 29-46. Dále citováno podle vydání DAVIDSON, Donald. What Metaphors Mean. In MARTINICH, A. P. (ed.), The Philosophy of Language, London: Routledge 1979, s. 430-441.

FREGE, Gottlob. Über Sinn und Bedeutung. Zeitschrift für Philosophie und philosophische Kritik. 1892, 100(1), s. 25-50 (česky O smyslu a významu. In FIALA, Jiří -

49 MÁCHA, J. Metaphor in Analytic Philosophy and Cognitive Science. Revista Portuguesa de Filosofia. 2019, 75(4), 2247-2286. 
NEUBAUER, Zdeněk - PINC, Zdeněk (eds.). SciPhi : Scientia Ẽ Philosophia: interni sbornik pro potřeby učitelu a studentů kateder základů vzdèlanosti, sdružených v Institutu základů vzdělanosti University Karlovy. Praha: Hrnčířství a nakladatelství Michal Jůza \& Eva Jůzová 1992).

GAHÉR, Fratišek. Fregeho filozofia matematiky a program logicizmu. In FREGE, G. Základy aritmetiky, Bratislava: Veda 2001.

MÁCHA, Jakub. Analytické teorie metafory: I. Počátky interakční teorie u I. A. Richardse. Studia philosophica. 2020, 67(1), s. 23-29.

MÁCHA, Jakub. Analytické teorie metafory: II. Interakční teorie M. Blacka. Studia philosophica. 2020, 67(2), s. 7-19.

MÁCHA, Jakub. Metaphor in Analytic Philosophy and Cognitive Science. Revista Portuguesa de Filosofia. 2019, 75(4), 2247-2286.

RICOEUR, Paul. The Metaphorical Process as Cognition, Imagination, and Feeling. In SACKS, S. (ed.), On Metaphor. Chicago: University of Chicago Press 1978, s. 141-157.

RORTY, Richard. Unfamiliar noises: I. Hesse and Davidson on metaphor, Proceedings of the Aristotelian Society, Supplementary Volumes. 1987, 61, s. 283-311.

WITTGENSTEIN's Nachlass. The Bergen Electronic Edition. Oxford: Oxford University Press 2000.

prof. Dr. phil. Jakub Mácha, Ph.D.

Katedra filozofie, Filozofická fakulta, Masarykova univerzita

Arna Nováka 1, 60200 Brno, Česká republika

macha@mail.muni.cz

Toto dílo Ize užít v souladu s licenčními podmínkami Creative Commons BY-NC-ND 4.0 International (https://creativecommons.org/licenses/by-nc-nd/4.0/legalcode). Uvedené se nevztahuje na díla či prvky (např. obrazovou či fotografickou dokumentaci), které jsou v díle užity na základě smluvní licence nebo výjimky či omezení př́slušných práv. 
